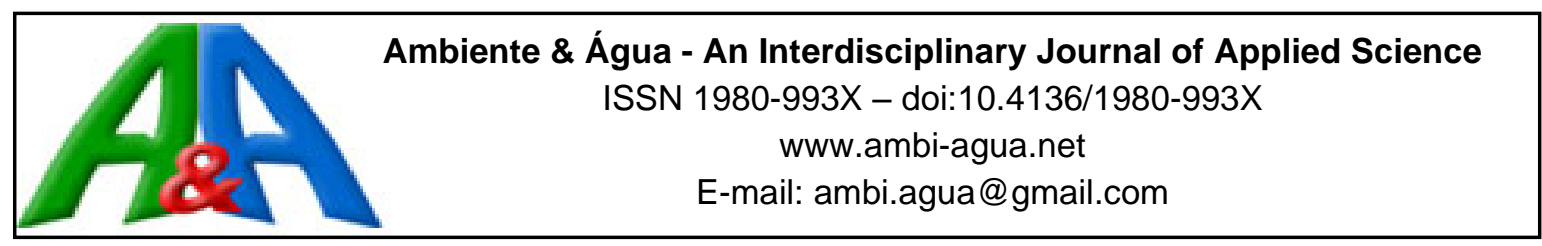

\title{
Application of polyelectrolytes for improving the dewatering performance of drinking water treatment sludge using geotextiles
}

\author{
ARTICLES doi:10.4136/ambi-agua.2723
}

Received: 18 Mar. 2021; Accepted: 13 Aug. 2021

\begin{abstract}
Livia Luiza de Souza Avancini*iD; Matheus Muller ${ }^{(D}$; Delma de Mattos Vidal
Departamento de Geotecnia. Instituto Tecnológico de Aeronáutica (ITA), Praça Marechal Eduardo Gomes, $\mathrm{n}^{\circ} 50$, CEP: 12228-900, São José dos Campos, SP, Brazil. E-mail: mrlmuller@gmail.com, delma@ita.br *Corresponding author. E-mail: liviasavancini@gmail.com
\end{abstract}

\begin{abstract}
The sludge generated at drinking water treatment plants (WTPs) is a high-moisture content residue, and therefore difficult to handle, transport, dispose of or recover. During the last decades, geotextile tubes have been successfully applied to reduce the residue volume, facilitate its handling and subsequent reuse. This study aimed to understand the factors that interfere in the filtration and dewatering efficiencies and to experimentally analyze the dewatering process of WTPs sludge, evaluating different test procedures and investigating the influence of the type and dosage of polymeric additives on dewatering performance. Geotextile cone dewatering tests and geotextile bag dewatering tests were performed, using four different woven geotextile samples and an aluminum sulfate WTP sludge sample. The results showed that the use of geotextile cone dewatering tests for geotextile selection and for additive selection and dosage was representative for the dewatering process intended, reflecting the results verified in the geotextile bag dewatering tests. Sludge chemical conditioning increased dewatering rate and solids retention during the tests' early stages, but it did not result in a higher final solids content sludge cake.
\end{abstract}

Keywords: dewatering systems, geosynthetics, waste management.

\section{Utilização de polieletrólitos para melhorar o desempenho de desaguamento de lodos de ETA em tubos geotêxteis}

\section{RESUMO}

O lodo gerado em estações de tratamento de água (ETAs) é um resíduo com alto teor de umidade e, portanto, de difícil manuseio, transporte, disposição final e valoração. Nas últimas décadas, tubos geotêxteis vêm sido utilizados com sucesso para o desaguamento deste resíduo, reduzindo seu volume, facilitando seu manuseio e possível reuso. O presente estudo foca no entendimento dos fatores que influenciam nas eficiências de filtração e desaguamento, através de ensaios de desaguamento com lodo de ETA, avaliando diferentes procedimentos de ensaio e investigando a influência do tipo e dosagem de condicionante químico no desempenho sistema de desaguamento em geotêxtil. Ensaios de cone e de bolsa foram realizados utilizando quatro tipos de geotêxteis tecidos e lodo com sulfato de alumínio. Os resultados demostraram que os ensaios de cone para a escolha do geotêxtil e condicionante químico foram satisfatórios, e que refletiram os resultados observados nos ensaios de bolsa de desaguamento de pequenas 
dimensões. Concluiu-se que o uso de condicionante químico acelera o desaguamento e a retenção de sólidos no início do ensaio, porém não resultou em maiores teores de sólidos finais.

Palavras-chave: geossintéticos, gestão de resíduos, sistema de desaguamento.

\section{INTRODUCTION}

Sludge generated at WTPs is often discharged to nearby hydric bodies and this practice affects water quality and aquatic life, increasing water turbidity, contaminating the water with the chemicals used in the treatment, and silting up the receiving streams. Frequently, WTP sludge is sent to a sewage treatment plant, transferring the problem and overwhelming the sewage treatment plant. Sludge disposal in landfills can also be a problem, as it involves high costs. Moreover, because of its high moisture content, WTP sludge is a difficult residue to handle and transport, and if not properly treated it may cause destabilization of the landfill.

Commonly used low-cost dewatering methods such as drying beds and evaporation lagoons may present difficulties involving climate variation susceptibility and land availability. In contrast, the high cost of mechanical methods such as filter-press and centrifuges leads to a growing concern about the optimization of the sludge treatment process and sludge cake future disposal. Regarding that, a preeminent dewatering method is the geotextile tube, holding both the advantages of the conventional and mechanical dewatering techniques. Several researchers have studied this dewatering technique, using geotextile tubes to reduce WTP sludge moisture content (Fowler et al., 1997; Guimarães et al., 2014; Avancini and Vidal, 2018).

The sludge generated by WTPs consists of water, the suspended solids present in raw water (organic and inorganic impurities), and part of the chemicals used during the water treatment process, such as chlorine, coagulants, flocculant aids, lime, caustic soda, and activated carbon. Water treatment facilities generated two types of residues: the sludge that results from the removal of the settled flocs from the bottom of the sedimentation basin, and the filters' backwash water. The amount of sludge generated by WTPs depends on the quality of the raw water and on the chemicals used in its treatment (Cornwell and Roth, 2011).

Different procedures applied to remove sludge from settling basins result in variable residue volumes and concentrations. For example, periodic manual cleaning requires a considerable amount of water to facilitate the removal of the sludge, using hoses and squeegees to direct the residue towards the discharge well, affecting the final volume and total solids content of the residue. Usually, settling basins are manually cleaned 3 to 12 times a year (Di Bernardo and Dantas, 2005).

Several authors have reported that the processes (coagulation mechanisms, flocculation velocity gradient) and chemicals (coagulants, flocculation aids) used during raw water treatment influence the sludge dewaterability and filterability. Those processes and chemicals will determine the sludge characteristics, such as the bound water content (interstitial, surface, and chemically bonded water) and the floc structure (Turchiuli and Fargues, 2004; Li et al., 2007). Muthukumaran and Ilamparuthi (2006) have related the dewatering performance of geotextile closed dewatering systems to the slurry particle-size distribution.

Knocke et al. (1987) examined the influence of the coagulation mechanism on the dewatering behavior of iron and aluminum hydroxide sludge samples. They reported that the sweep coagulation mechanism produces larger flocs with a greater amount of water incorporated in their structure. That is, flocs formed by sweep coagulation generate less dense flocs that will present lower total solids content after being submitted to the dewatering process. Whereas flocs produced by adsorption-charge neutralization are smaller, but denser and therefore have higher rates of water removal. However, the total water content of the floc should not be the main concern, but rather the bound water content, which is the water that cannot be easily removed mechanically. Also, in conventional WTP, the coagulation mechanism is 
usually sweep coagulation because of its efficiency in turbidity removal, precisely because sweep coagulation produces larger flocs that settle faster on the settling basin.

Using chemical accelerants may be necessary to enhance the efficiency of sludge dewatering. The choice of the most appropriate type and dosage of flocculant and its mixing conditions is based on empiric procedures (Oliveira and Vidal, 2020). During sludge dewatering, it is critical to understand the interactions between sludge particles and polymers to achieve maximum dewatering performance with minimum conditioning polymer requirements. Flocculation is considered a key step in dewatering processes, but because of the chemicals added during the purification of water, the sludge from WTPs is already composed of flocs (and water), and thus the need for additional use of chemical accelerants before the dewatering process must be carefully evaluated.

Several field and laboratory testing methods have been developed to access the dewatering performance of geotextile tubes. Small-scale tests are performed using a small representative sample of the sludge and provide initial evidence of the system's filtration and dewatering behavior. These tests can also be useful to verify the need for sludge chemical conditioning and to determine the additive optimal dose (Avancini and Vidal, 2018; Driscoll et al., 2016).

Due to its simplicity and speed of obtaining results, the geotextile cone dewatering test is useful for geotextile selection and for evaluating the need for chemical conditioning. It is also suitable for the selection of the most appropriate additive and its optimum dosage for the sludge studied. The GCDT is a non-standardized test, but it has been proposed and applied in the literature, although with procedure variations (Lawson, 2008; Avancini and Vidal, 2018), and some manufacturers of geotextile tubes even provide brochures with directions for its realization. Nevertheless, the GCDT does not replace the GBDT, since the amount of sludge tested is small and no pressure occurs during filling.

The geotextile bag dewatering test (GBDT) provides information on final solids concentration of the retained residue, dewatering rate, effluent total solids content, and effectiveness of chemical accelerants, giving an insight into the expected behavior of the fullscale application. The GBDT was proposed and applied by several authors, with some variations (Koerner and Koerner, 2010; Guimarães et al., 2014; Ratnayesuraj and Bhatia, 2018). The most commonly used standards on this matter are the GRI GT15 (Geosynthetic Research Institute, 2009) and the ASTM D7880/7880M-13 (ASTM, 2013). Both standards propose a method for the GBDT, also known as the pillow test, and are similar.

The test procedure consists of pouring the sludge sample into a 1-m-long pipe attached to a small, pillow-shaped, geotextile bag until the bag is fully filled. The amount of filtrate collected at given interval times, the flow rate, and the quantity of sediment that passes through the geotextile bag are measured. The GRI GT15 also suggests that the hydraulic head on the pipe attached to the bag should be monitored over time.

Tominaga (2010) performed GBDTs in accordance with the GRI GT15 recommendation and due to difficulties during the test execution small modifications were proposed. Avancini and Vidal (2018) performed GCDTs and GBDTs adopting the modifications proposed by Tominaga (2010). Sludge samples collected from two different WTPs were tested and dewatering and filtration efficiencies were calculated and compared for each test performed. It was verified that the chemicals and processes employed during the purification of water have a significant influence on the WTP residue dewaterability. Results obtained from the tests also indicate that the sludge sample composed of larger flocs and with higher total solids content presented greater retention of solids at the beginning of the GBDT but lower dewatering efficiency. However, both sludge samples reached an adequate filtration efficiency after a period of time, and it was concluded that the geotextile dewatering system functioned properly for both samples tested.

Within this context, the purpose of the present work is to study the WTP sludge dewatering 
process in closed geotextile systems using polymers as dewatering accelerants. In addition, the factors that influence the filtration and dewatering efficiencies, the dewatering rate, and the final quality of the filtrate and of the sludge cake are also investigated.

\section{MATERIALS AND METHODS}

\subsection{Test materials}

Four different types of polypropylene woven geotextiles were used in the present research. Table 1 shows the characteristic properties of these geotextiles.

The sludge sample used in these tests was collected at a water treatment plant located in the municipality of Taubaté, state of São Paulo. Taubaté WTP operates in a complete cycle, treating raw water captured in the Una and Paraiba do Sul Rivers. During the water treatment process in this WTP, aluminum sulfate is used as a coagulant and a non-ionic high molecular weight polymer is applied as a flocculation aid. Settling basins sludge removal at this WTP is performed manually between one or two times a month and the sludge sample tested was collected during the conventional draining and desilting operation of one of the settling basins. The characteristics of the tested sludge sample were initial total solids content of $9.51 \%$ (APHA et al., 1998), and volatile solids content of 29.83\% (APHA et al., 1998). The solids' specific gravity was determined according to ABNT NBR NM 52 (ABNT, 2009), obtaining a value of $2.57 \mathrm{~g} / \mathrm{cm}^{3}$.

To verify the necessity and the effects of the use of polyelectrolytes for sludge chemical conditioning, eight commercial synthetic polymers were tested in different concentrations and dosages. Those chemical conditioners vary from anionic, non-ionic, and cationic polymers, and their characteristics are presented in Table 2. All polymers used were prepared in $0.5 \%$ concentration solution.

\subsection{Geotextile cone dewatering tests}

GCDTs were performed and divided into three test groups: GCDTs for geotextile selection; GCDTs for the selection of the chemical additive; and GCDTs for the determination of the chemical additive's optimum dosage.

The GCDT procedure adopted in this work was defined after preliminary tests were carried out to analyze the various suggested procedures in the literature. It consisted of pouring 400 $\mathrm{cm}^{3}$ of WTP sludge into a previously folded cone-shaped geotextile, as shown in Figure 1a, and measuring the retained solids amount, filtrate solids content and volume collected over time. The test duration was set at 25 minutes so that there was sufficient time for the dripping to stop.
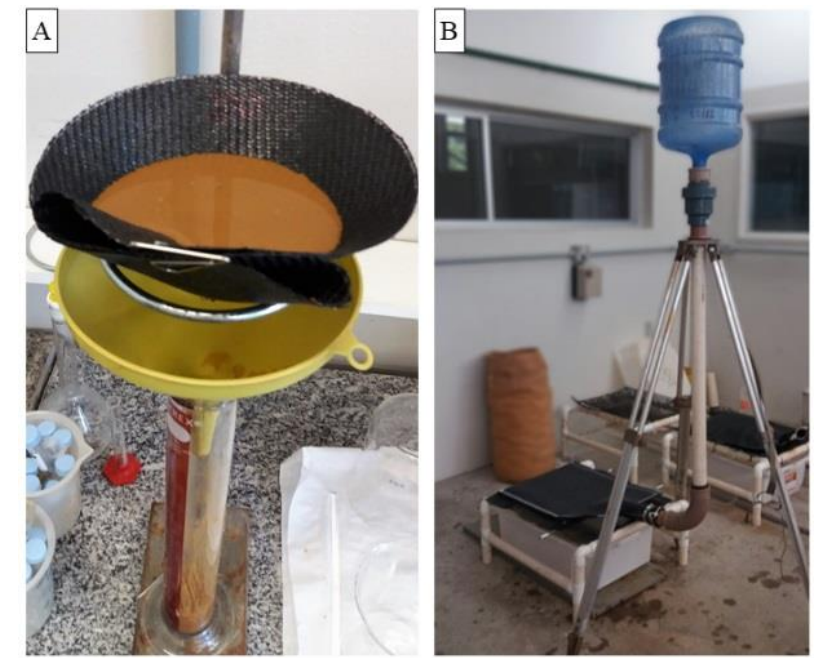

Figure 1. Assembly of tests: a) geotextile cone dewatering test; b) geotextile bag dewatering test. 
Table 1. Properties of the geotextiles utilized.

\begin{tabular}{|c|c|c|c|c|c|c|c|c|c|}
\hline \multirow{2}{*}{ Property } & \multirow{2}{*}{ Test method } & \multicolumn{8}{|c|}{ Woven geotextile test specimens } \\
\hline & & \multicolumn{2}{|c|}{ GTX 1} & \multicolumn{2}{|c|}{ GTX 2} & \multicolumn{2}{|c|}{ GTX 3} & \multicolumn{2}{|c|}{ GTX 4} \\
\hline Composition & - & \multicolumn{2}{|c|}{ Polypropylene } & \multicolumn{2}{|c|}{ Polypropylene } & \multicolumn{2}{|c|}{ Polypropylene } & \multicolumn{2}{|c|}{ Polypropylene } \\
\hline Colour & - & \multicolumn{2}{|c|}{ Black } & \multicolumn{2}{|c|}{ Black } & \multicolumn{2}{|c|}{ Black } & \multicolumn{2}{|c|}{ Black } \\
\hline Thickness (mm) & ISO 98631 & \multicolumn{2}{|c|}{1.66} & \multicolumn{2}{|c|}{1.88} & \multicolumn{2}{|c|}{1.21} & \multicolumn{2}{|c|}{0.931} \\
\hline Mass per unit area $\left(\mathrm{g} / \mathrm{m}^{2}\right)$ & ISO 9864 & \multicolumn{2}{|c|}{483} & \multicolumn{2}{|c|}{481} & \multicolumn{2}{|c|}{409} & \multicolumn{2}{|c|}{284} \\
\hline \multirow{2}{*}{ Wide width tensile strength $(\mathrm{kN} / \mathrm{m})$} & ISO 10319 & MD & $\geq 105$ & MD & $\geq 105$ & MD & $\geq 80$ & MD & $\geq 55$ \\
\hline & ISO 10319 & CMD & $\geq 105$ & CMD & $\geq 105$ & CMD & $\geq 80$ & CMD & $\geq 55$ \\
\hline \multirow{2}{*}{ Elongation at maximum load (\%) } & ISO 10319 & MD & $\leq 10$ & $\mathrm{MD}$ & $\leq 10$ & MD & $\leq 15$ & MD & $\leq 15$ \\
\hline & ISO 10319 & CMD & $\leq 10$ & CMD & $\leq 10$ & CMD & $\leq 15$ & CMD & $\leq 15$ \\
\hline Permeability (m/s) & ISO 11058 & \multicolumn{2}{|c|}{$30 \times 10^{-3}$} & \multicolumn{2}{|c|}{$83 \times 10^{-3}$} & \multicolumn{2}{|c|}{$13 \times 10^{-3}$} & \multicolumn{2}{|c|}{$15 \times 10^{-3}$} \\
\hline Opening size $\mathrm{O}_{90}(\mu \mathrm{m})$ & ISO 12956 & \multicolumn{2}{|c|}{149} & \multicolumn{2}{|c|}{530} & \multicolumn{2}{|c|}{126} & \multicolumn{2}{|c|}{185} \\
\hline
\end{tabular}

Table 2. Properties of the polymers utilized.

\begin{tabular}{lcccccccc}
\hline Properties & A4105 & A4110 & A4120 & C8125 & C8165 & C8185 & C4030 & N020 \\
\hline $\begin{array}{l}\text { Chemical } \\
\text { components }\end{array}$ & $\begin{array}{c}\text { Acrylamide } \\
\text { Acrylic } \\
\text { acid }\end{array}$ & $\begin{array}{c}\text { Acrylamide } \\
\text { Acrylic acid }\end{array}$ & $\begin{array}{c}\text { Acrylamide } \\
\text { Acrylic acid }\end{array}$ & $\begin{array}{c}\text { Acrylamide } \\
\text { Cationic } \\
\text { quaternized } \\
\text { monomer }\end{array}$ & $\begin{array}{c}\text { Acrylamide } \\
\text { Cationic } \\
\text { quaternized } \\
\text { monomer }\end{array}$ & $\begin{array}{c}\text { Acrylamide } \\
\text { Cationic } \\
\text { quaternized } \\
\text { monomer }\end{array}$ & $\begin{array}{c}\text { Acrylamide } \\
\text { Acrylamide }\end{array}$ \\
\hline Pype & Powder & Powder & Powder & Powder & Powder & Powder & Emulsion & Emulsion \\
\hline $\begin{array}{l}\text { Molecular } \\
\text { weight }\end{array}$ & $\begin{array}{c}\text { Very low } \\
\text { anionic }\end{array}$ & Low anionic & $\begin{array}{c}\text { Low to } \\
\text { medium } \\
\text { anionic }\end{array}$ & Low cationic & $\begin{array}{c}\text { Medium to high } \\
\text { cationic }\end{array}$ & High cationic & $\begin{array}{c}\text { High } \\
\text { cationic }\end{array}$ & Non-ionic \\
\hline Density $\left(\mathrm{g} / \mathrm{cm}^{3}\right)$ & 0.75 & 0.75 & 0.75 & 0.75 & High & Very high & High & High \\
\hline $\mathrm{pH}($ solution) & $6-8$ & $6-8$ & $6-8$ & $4-6$ & $4-6$ & 4.75 & $4-6$ & $3-6$ \\
\hline
\end{tabular}




\subsection{Geotextile bag dewatering tests}

The tests were carried out in the laboratory at Instituto Tecnológico de Aeronáutica (ITA) and the test procedure adopted consists of pouring $50 \mathrm{~L}$ of homogenized sludge, with the aid of a reservoir equipped with a butterfly valve, into a 1-m-long pipe attached to a geotextile bag until the bag is fully filled. A tripod was used to support the feeding pipe that was connected to the geotextile bag through a lateral sleeve made in the bag. The system was placed over a plastic container to collect the effluent throughout the time, as shown in Figure 1b. The volume and solids content (APHA et al., 1998) of the filtrate were measured. To assess moisture content reduction in the sludge cake, 5 collection points were opened in each bag and the moisture content of the retained residue was measured after 24, 48, 96, and $192 \mathrm{~h}$ of the test beginning.

GBDTs were performed to compare the behavior of the WTP sludge with and without chemical conditioning, in its optimum dosage and in a reduced dosage.

\section{PARAMETERS TO EVALUATE DEWATERING PERFORMANCE}

Regardless of the type of sludge to be dewatered, the same performance parameters are evaluated for geotextile dewatering systems. It is important that the sludge dewaters quickly, that the geotextiles retain most of the solid particles, that the effluent has reduced turbidity, and that the retained material possesses low water content.

These dewatering performance parameters are presented in this topic, encompassing Filtration Efficiency (FE), Dewatering Efficiency (DE), Percent Dewatered (PD), Particle Loss per unit area (PP), Retention Effectiveness $\left(E_{R}\right)$, and Dewatering Rate Effectiveness $\left(E_{D R}\right)$.

Moo-Young et al. (2002) suggest that FE (\%) represents the geotextile dewatering systems capacity to retain solids and can be obtained by comparing the filtrate total solids content with the sludge sample initial total solids content, as given in Equation 1:

$$
F E=\frac{T S_{\text {initial }}-T S_{\text {final }}}{T S_{\text {inicial }}} \times 100(\%)
$$

Where $T S_{\text {initial }}$ is the sludge initial total solids content $(g / L)$, and $T S_{\text {final }}$ is the filtrate final total solids content $(g / L)$.

$D E(\%)$ is a parameter related to the total solids content of the retained residue and can be obtained by comparing the initial sludge total solids percentage and the retained residue total solids percentage (Moo-Young et al., 2002), as shown in Equation 2:

$$
D E=\frac{P S_{\text {final }}-P S_{\text {initial }}}{P S_{\text {inicial }}} \times 100(\%)
$$

Where $P S_{\text {initial }}$ is the initial percentage of solids (\%) and $P S_{\text {final }}$ is the final average percentage of solids (\%).

Given the dependence of DE on slurry characteristics, Bhatia et al. (2013) proposed an efficiency measure that is independent of initial slurry conditions named Percent Dewatered (PD), which may be a more meaningful index as it ranges from $0-100 \%$ regardless of initial slurry concentration. PD is defined by Equation 3:

$$
P D=\frac{w_{\text {initial }}-w_{\text {final }}}{w_{\text {inicial }}} \times 100(\%)
$$

Where $w_{\text {initial }}$ is the sludge initial water content $(\%)$ and $w_{\text {final }}$ is sludge final water content $(\%)$. 
$P P\left(\mathrm{~g} / \mathrm{m}^{2}\right)$ relates to the particle loss throughout the geotextile surface (Satyamurthy and Bhatia, 2009) and is given by Equation 4:

$$
P P=\frac{T S_{\text {final }}}{A}\left(\frac{g}{m^{2}}\right)
$$

Where $T S_{\text {final }}$ is the filtrate total solids ( $\mathrm{g}$ ) and $A$ is the effective geotextile area during dewatering $\left(\mathrm{m}^{2}\right)$.

The effectiveness of the use of the chemical conditioning agent in terms of improvement in particle retention, named Retention Effectiveness $\left(E_{R}\right)$, can be determined from the reduction of the loss of particles as a result of the polymer addition, as given by Equation 5 (Satyamurthy and Bhatia, 2009).

$$
E_{R}=\frac{P_{\text {sludge }}-P_{\text {cond. sludge }}}{P_{\text {sludge }}} \times 100(\%)
$$

Where $P_{\text {sludge }}$ is the loss of particles that occurred in the test using sludge without chemical conditioning $(g)$ and $P_{\text {cond. sludge }}$ is the loss of particles that occurred in the test using polymer conditioned sludge $(g)$.

In tests without additional pressure to the sludge hydraulic head, such as in GCDT and GBDT, and depending on the sludge characteristics, the determination of the test time may be difficult, since the dewatering system can take a long time to finish the drip. Thus, in these cases, it would be more appropriate to determine the effectiveness of the polymer by relating the test's dewatering rate, rather than the test's dewatering time.

So, in this paper it is proposed that this parameter should be calculated by relating the dewatering rate calculated in the test without polymer addition, to the dewatering rate calculated in the test performed with the polymer-conditioned sludge, for a predetermined time interval, that in this study was 25 min for GCDTs and $24 \mathrm{~h}$ for the GBDTs. Thus, we propose a new index, named Dewatering Rate Effectiveness $\left(E_{D R}\right)$, to evaluate the effectiveness of the polymer regarding the dewatering rate increase. The $E_{D R}$ is basically the percentage change in dewatering rate and is defined as in Equation 6:

$$
E_{D R}=\frac{D R_{\text {cond.sludge }}-D R_{\text {sludge }}}{D R_{\text {sludge }}} \times 100(\%)
$$

Where $D R_{\text {sludge }}$ is the dewatering rate in the test with sludge without polymer addition $\left(\mathrm{cm}^{3} / \mathrm{s}\right)$ and $D R_{\text {cond. sludge }}$ is the dewatering rate in the test with polymer-conditioned sludge $\left(\mathrm{cm}^{3} / \mathrm{s}\right)$.

\section{RESULTS AND DISCUSSION}

\subsection{Geotextile cone dewatering tests}

Geotextile cone dewatering tests for the geotextile selection were conducted using sludge without chemical conditioning, in triplicates, and with the geotextiles GTX 1, GTX 2, GTX 3, and GTX 4. The results obtained are presented in Figure 2a. It was observed during the experiments that the GCDTs with the GTX 1 specimens presented a greater filtrate volume. In the tests performed with geotextiles, GTX 3 and GTX 4 clogging was observed, exhibiting water line formation on top of the retained residue and a small filtrate volume. During the tests, it was possible to visually perceive that the GTX 1 presented higher solids retention when compared to GTX 2. Thus, GTX 1 was selected to continue the tests. 

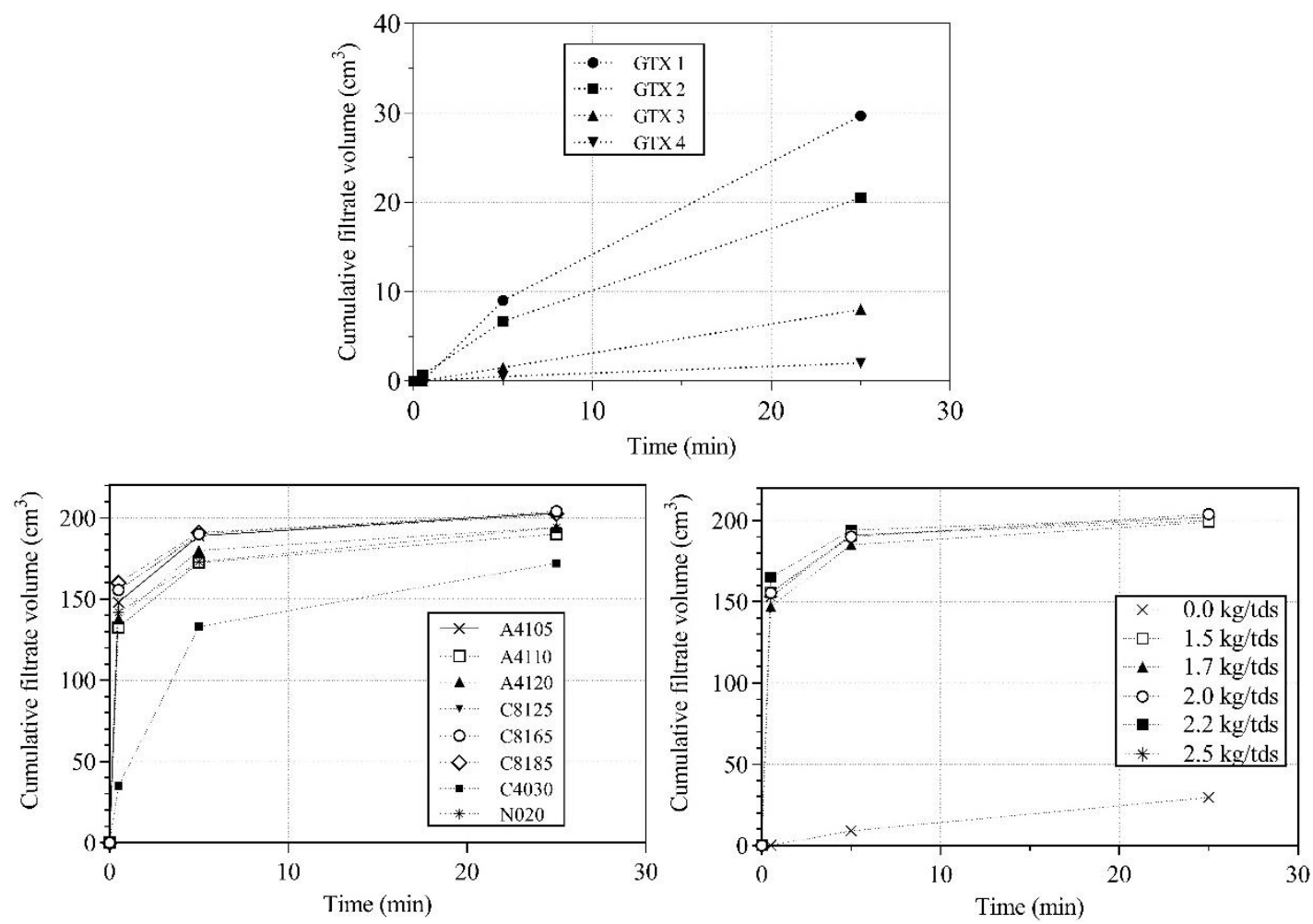

Figure 2. Cumulative filtrate volume $\left(\mathrm{cm}^{3}\right)$ over time: a) GCDTs for geotextile selection; b) GCDTs for polymer section; c) GCDTs for polymer dosage determination.

Then, it was necessary to select the appropriate concentration of the aqueous polymer solution. The concentration of the solution must be compatible with the viscosity of the polymer and with the sludge sample total solids content, the instructions from the manufacturer in the products brochure must also be considered. A solution produced with a too high polymer concentration will be thick, difficult to dose, and will demand a very high velocity gradient to promote its dispersion in the sludge. In contrast, a solution with insufficient polymer concentration will require a large volume of the solution, and consequently a large volume of water, for the proper conditioning of the sludge. Thus, polymer solutions were prepared in various concentrations and after preliminary mixing tests, the $0.5 \%$ polymer solution was adopted and used satisfactorily in the subsequent tests.

The appropriate polymer for the sludge test was determined utilizing GCDTs with the use of 8 different polymers. Previous cone tests were also performed to confirm that the dosage chosen was appropriate. It was then decided to dose $2 \mathrm{~g}$ of polymer per $\mathrm{kg}$ of dry solids. Figure $2 b$ shows the cumulative filtrate volume collected in each test over time.

All the products tested showed good flocculation for the WTP sludge sample, yet it was observed that polymer $\mathrm{C} 4030$ required a higher dosage than the dosage considered satisfactory for the other polymers. Thus, if the polymer C4030 were to be used in a real-scale dewatering system, it would be necessary to evaluate the economic viability of this product. Since the volume of polymer used would be considerably larger, the price of the product is an important factor to be taken into consideration.

The effectiveness of the polymer regarding the solids retention improvement $\left(E_{R}\right)$ and the effectiveness of the polymer regarding the dewatering rate increase were calculated $\left(E_{D R}\right)$. Filtration efficiency (FE), dewatering efficiency (DE), and percent dewatered (PD) were also determined.

The polymer $\mathrm{C} 8165$ obtained the best results in relation to $\mathrm{DE}, \mathrm{PD}$, and the effectiveness of the polymer in increasing the dewatering rate $\left(E_{D R}\right)$. On the other hand, the polymer N020 showed the best results in relation to the FE and the effectiveness of the polymer in improving 
solids retention $\left(\mathrm{E}_{\mathrm{R}}\right)$. Thus, to make the selection of the most appropriate chemical additive, it is necessary to consider the balance between these criteria, seeking the best retention/permeability relation and prioritizing each project's needs.

Based on the results obtained, polymer C8165 was selected to be used in the geotextile bag dewatering tests, as it presented satisfactory results in all the analyzed criteria, for not having adhered in the geotextile, a situation that could lead to the clogging of the geotextile, and for being easy to handle in the desired concentration. The test results can be seen in Table 3 .

Table 3. Results obtained in the GCDTs for polymer selection and for different polymer dosages.

\begin{tabular}{ccccccc}
\hline Polymer & Dosage $(\mathrm{kg} / \mathrm{tds})$ & $\mathrm{FE}(\%)$ & $\mathrm{DE}(\%)$ & $\mathrm{PD}(\%)$ & $\mathrm{E}_{\mathrm{R}}(\%)$ & $\mathrm{E}_{\mathrm{DR}}(\%)$ \\
\hline \multicolumn{7}{c}{ GCDTs for polyelectrolyte selection } \\
A4105 & 2 & 97.9 & 94.5 & 52.5 & 45.6 & 584.3 \\
A4110 & 2 & 98.1 & 83.5 & 49.2 & 50.9 & 540.4 \\
A4120 & 2 & 98.2 & 86.8 & 50.3 & 52.1 & 553.9 \\
C8125 & 2 & 98.3 & 94.1 & 52.4 & 56.7 & 580.9 \\
C8165 & 2 & 98.3 & 95.9 & 53.0 & 53.9 & 587.6 \\
C8185 & 2 & 98.5 & 93.5 & 52.3 & 61.4 & 577.5 \\
C4030 & 2 & 98.6 & 70.4 & 44.7 & 61.8 & 479.8 \\
N020 & 2 & 98.6 & 87.1 & 50.4 & 62.4 & 553.9 \\
\hline \multicolumn{7}{c}{} \\
\hline- & GCDTs for polyelectrolyte dosage determination & \\
C8165 & 0 & 97 & 7.5 & 7.5 & - & - \\
C8165 & 1.5 & 96.4 & 90.5 & 51.5 & 0.9 & 574.2 \\
C8165 & 1.7 & 98.8 & 91.9 & 51.8 & 67.5 & 570.8 \\
C8165 & 2.2 & 98.3 & 95.9 & 53 & 53.9 & 587.6 \\
C8165 & 2.5 & 98.8 & 94.5 & 52.5 & 69.2 & 580.9 \\
\hline
\end{tabular}

To determine the most appropriate dosage for the WTP sludge chemical conditioning, several tests were carried out by varying the dosage of polymer C8165 between 1.5 and $2.5 \mathrm{~kg}$ of polymer per ton of dry solids, that is, per ton of solids contained in the sludge. The graph of Figure $2 \mathrm{c}$ shows the filtrate volume collected over time for the different dosages. It is observed that the dosage that presented the largest volume of effluent was the dosage of $2 \mathrm{~kg}$ of polymer per ton of dry sludge $(2.0 \mathrm{~kg} / \mathrm{tds})$. This dosage was considered the optimum dosage since from this amount, the increase of the polymer dose did not increase the filtrate volume.

The effectiveness of the polymer in terms of improvement in the solids retention $\left(E_{R}\right)$ and the effectiveness of the polymer related to the increase in dewatering rate $\left(E_{D R}\right)$ were evaluated for the tests with the different polymer dosages investigated. Filtration efficiency (EF), dewatering efficiency (ED), and percent dewatered (PD) efficiencies were also determined. The results can be seen in Table 3 .

The calculated results confirm that the value of $2 \mathrm{~kg} / \mathrm{tds}$ can be considered the optimum dosage for the WTP sludge sample.

\subsection{Geotextile bag dewatering tests}

The geotextile bag dewatering tests were conducted using GTX 1 test specimens and polymer C8165 at the optimum dosage determined by the cone dewatering tests $(2.0 \mathrm{~kg} / \mathrm{tds})$ and at a $50 \%$ reduced dosage $(1.0 \mathrm{~kg} / \mathrm{tds})$ to verify the effectiveness of the polymer and compare the results of these tests with the results of the sludge tests without any chemical conditioning. Figure 3a shows the filtrate volumes collected over time for the different dosages. 


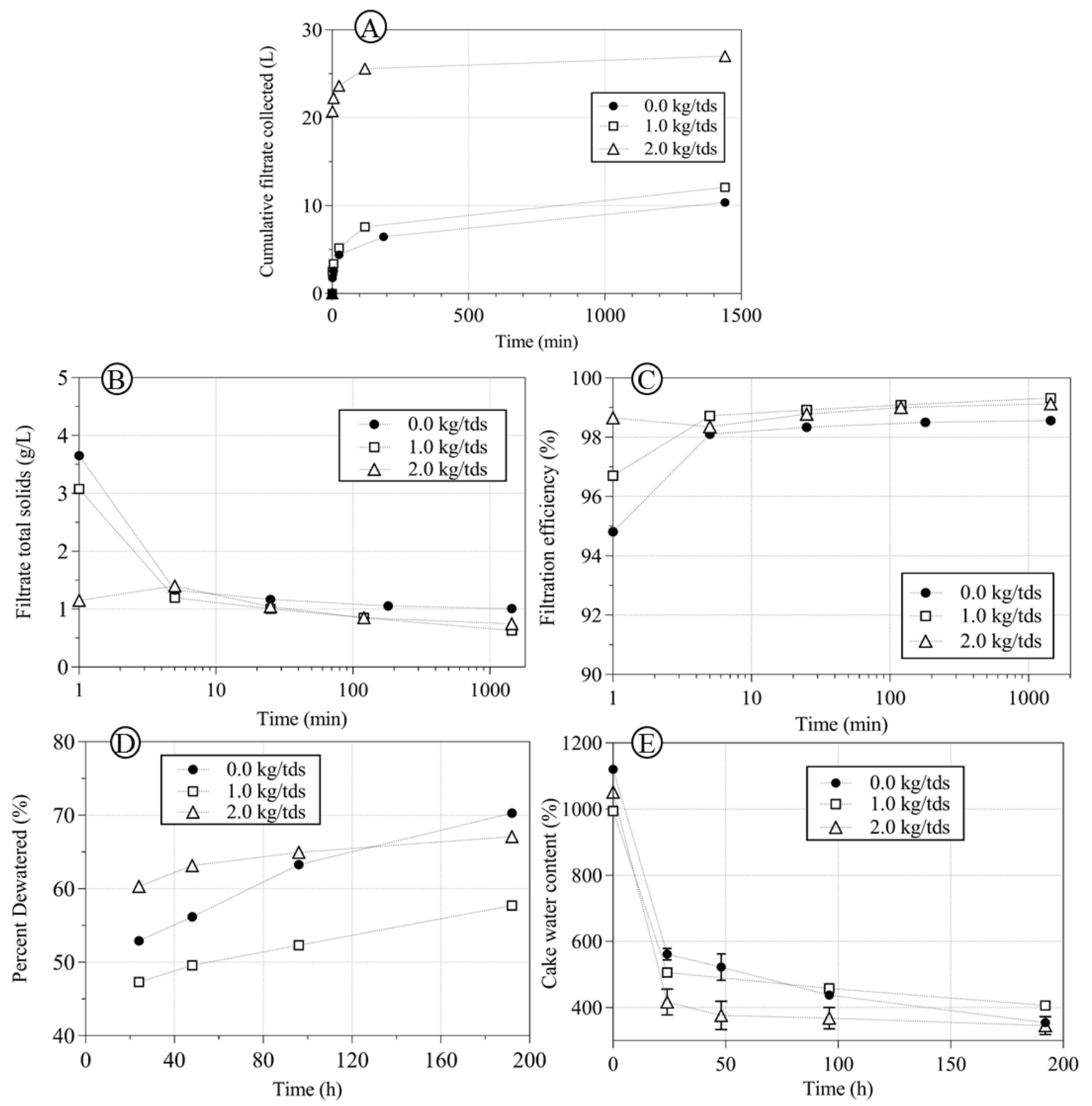

Figure 3. GBDTs results. a) cumulative filtrate volume $\left(\mathrm{cm}^{3}\right)$ over time; b) filtrate total solids ( $\left.\mathrm{g} / \mathrm{L}\right)$ over time; c) filtration efficiency (\%) over time; d) percent dewatered (\%) over time; e) average cake water content $(\%)$ over time.

It was noticed that the test with the sludge conditioned at the optimum dosage presented a significantly higher performance than the ones with conditioned sludge at a reduced dosage. The tests at the dosage of $50 \%$ of the optimum dosage $(1.0 \mathrm{~kg} / \mathrm{tds})$ showed a small increase over the tests without chemical conditioning. Table 4 shows output data obtained in the GBDTs for the different dosages.

Table 4. Results obtained in the GBDTs for different polymer dosages.

\begin{tabular}{ccccccc}
\hline $\begin{array}{c}\text { Polymer dosage } \\
(\mathrm{kg} / \mathrm{tds})\end{array}$ & $\begin{array}{c}\mathrm{PS}_{\text {initial }} \\
(\%)\end{array}$ & $\begin{array}{c}\mathrm{w}_{\text {initial }} \\
(\%)\end{array}$ & $\begin{array}{c}\text { Geotextile bag } \\
\text { dimensions }\left(\mathrm{cm}^{2}\right)\end{array}$ & $\begin{array}{c}\text { Filling } \\
\text { time }(\mathrm{s})\end{array}$ & $\begin{array}{c}\text { Volume of sludge } \\
\text { admitted }(\mathrm{L})\end{array}$ & $\begin{array}{c}\mathrm{PP}\left(\mathrm{g} / \mathrm{m}^{2}\right) \\
24 \mathrm{~h}\end{array}$ \\
\hline 0.0 & 8.2 & 1119.5 & 2228.3 & 90 & 27.2 & 35.6 \\
1.0 & 9.1 & 994.3 & 2222.6 & 123 & 39.3 & 34.8 \\
2.0 & 8.7 & 1050.6 & 2225 & 115 & 28 & 67.6 \\
\hline
\end{tabular}

It can be seen in Table 4 that the test at the optimum dosage $(2.0 \mathrm{~kg} / \mathrm{tds})$ had greater particle 
loss per unit area than the other two tests. However, it should be remembered that the filtrate volume collected was also considerably higher. Since the quantity of solids is given in $\mathrm{g} / \mathrm{L}$, even a lower total solids value can lead to a greater amount of solids passing in proportion to the filtrate volume collected.

Through analyzing the filtrate total solids over time, it can be seen in Figure $3 b$ that the test with the conditioned sludge at the optimum dosage showed the best solids retention in the first 5 minutes of the test. However, after this period, it was observed that the retention in the tests without chemical conditioning and with reduced dosage conditioning showed a substantial improvement, since the amount of solids decreased significantly, indicating the formation of a filter cake.

After 25 minutes of testing, the amount of total solids in the filtrate collected in the tests with sludge without chemical conditioning decreased less, tending to keep stable, while in the other two tests the amount of solids in the filtrate continued to decrease until the end of the test. These results are also reflected in the filtration efficiency curves, as can be seen in Figure 3c.

Although it had lower filtration efficiency at the beginning, after a certain period, the 1.0 $\mathrm{kg} / \mathrm{tds}$ dosage test had slightly higher filtration efficiency than the sludge test at the optimum dosage. On the other hand, as shown in Figure 3d, the $1.0 \mathrm{~kg} / \mathrm{tds}$ dosage test showed substantially less PD than the test at the optimum dosage.

This shows how insufficient polymer dosing can impair the performance of the system. An excessive dosage of polymer may also cause problems and decrease the system's dewatering efficiency, producing higher moisture content cakes. Hence the importance of performing reliable laboratory investigations to determine optimal polymer dosage.

The percent dewatered (PD) represents the reduction in the cake moisture content. As seen in Figure 3d, the test that presented the greatest reduction in moisture content was the one using sludge without chemical conditioning. The results of the tests with sludge conditioned at 1.0 $\mathrm{kg} / \mathrm{tds}$ dosage, regarding the cake moisture content reduction, were not satisfactory, presenting the worst performance of the three tests.

In terms of the effectiveness of the polymer regarding the solids retention improvement $\left(E_{R}\right)$, considering the total amount of solids present in the filtrate, the GBDT with sludge at optimum dosage $(2.0 \mathrm{~kg} / \mathrm{tds})$ showed an average of $28.5 \%$ effectiveness, while the GBDT with sludge at the reduced dosage $(1.0 \mathrm{~kg} / \mathrm{tds})$ showed $17 \%$ efficacy.

The effectiveness of the polymer regarding the increase in the dewatering rate $\left(\mathrm{E}_{\mathrm{DR}}\right)$, considering the filtrate volume collected in the first $24 \mathrm{~h}$ of the test, was on average $160.4 \%$ in the GBDT with the sludge at optimum dosage $(2.0 \mathrm{~kg} / \mathrm{tds})$, while GBDT with sludge at a reduced dosage $(1.0 \mathrm{~kg} / \mathrm{tds})$ showed only $16.6 \%$ effectiveness, on average.

To examine temporal moisture content reduction in the sludge cake, after the last filtrate collection, that is, after $24 \mathrm{~h}$ of the beginning of the test, 5 collection points were opened in each bag. The cake water content of samples collected in the GBDT with the conditioned sludge was significantly lower during the first days of the test, but the final cake moisture after 8 days did not present such a great difference when compared to the final moisture of the residue samples collected in the test without the polymer.

It was noticed that the moisture measured for all the collected samples from the center area of the bag were higher than in the other points, ranging from $634 \%$ (after $24 \mathrm{~h}$ ) to $379 \%$ (after $192 \mathrm{~h}$ ) in the GBDTs without chemical conditioning and between $423 \%$ (after $24 \mathrm{~h}$ ) and $351 \%$ (after $192 \mathrm{~h}$ ) in the GBDTs with sludge at optimal polymer dosage.

The mean values of the cake water content over time were also calculated. The results are shown in Figure 3e. It can be observed that the GBDT with the sludge conditioned at reduced dosage did not present satisfactory results regarding the final moisture content of the retained residue.

Results obtained in the test with the conditioned sludge at the optimum dosage did not 
affect the final moisture of the residue, and thus it was concluded that the selection and dosage of the polymer determined by the geotextile cone dewatering tests was adequate.

It was observed that the polymer was effective in increasing the dewatering rate at the beginning of the tests. However, after eight days, the final moisture content of the conditioned sludge cake was similar to the test using sludge without polymer. Thus, the use of the polymer did not present significant advantages regarding the decrease of cake final moisture content for the WTP sludge sample tested.

\section{CONCLUSIONS}

The results obtained showed that the use of GCDTs for geotextile selection, additive selection and dosage was representative of the dewatering process intended, reflecting the results verified in the GBDTs.

Regarding the sludge chemical conditioning, the importance of carrying out reliable tests to determine polymer dosage was observed in this research, since an excessive or insufficient dosage may impair the dewatering performance of the system. Sludge conditioning at optimum dosage improved solids retention in the GBDTs, presenting an average effectiveness of $28.5 \%$, and also led to an average effectiveness of $160.4 \%$ regarding the increase in the dewatering rate, but it did not decrease the cake's final moisture content.

Depending on the residue characteristics and design assumptions, variations in the degrees of importance for the efficiency parameters should take place. For example, if the slurry to be dewatered presents hazardous contaminated material in its composition, the effectiveness related to the solids retention should be given a greater weight than the effectiveness related to the dewatering rate. On the other hand, for slurries composed mostly of water and soil particles, it is reasonable to attribute greater weight to the dewatering rate.

\section{ACKNOWLEDGMENTS}

The authors would like to acknowledge the Aeronautics Institute of Technology (ITA), Sabesp, and Huesker. This study was financed by the Coordenação de Aperfeiçoamento de Pessoal de Nivel Superior - Brasil (CAPES) - Finance Code 001.

\section{REFERENCES}

ABNT. NBR NM 52: Agregado miúdo - Determinação da massa específica e massa específica aparente. Rio de Janeiro, 2009.

APHA; AWWA; WEF. Standard Methods for the Examination of Water and Wastewater. 20. ed. Washington, 1998.

ASTM. D7880/D7880M: Standard Test Method for Determining Flow Rate of Water and Suspended Solids Retention from a Closed Geosynthetic Bag. West Conshohocken, 2013. http://dx.doi.org/10.1520/D7880_D7880M-13

AVANCINI, L. L. S.; VIDAL, D. M. Influence of water treatment plant sludge characteristics on its dewaterability in geotextile closed systems. In: INTERNATIONAL CONFERENCE ON GEOSYNTHETICS, 11., 16-21 Sep. 2018, Seoul. Proceedings[...] Seoul: IGS, 2018. p. 1-8. 
BHATIA, S. K.; MAURER, B. W.; KHACHAN, M. M.; GRZELAK, M. D.; PULLEN, T. S. Performance indices for unidirectional flow conditions considering woven geotextiles and sediment Slurries. Sound Geotechnical Research to Practice: Honoring Robert D. Holtz II, p. 318-332, 2013.

CORNWELL, D. A.; ROTH, D. K. Water Treatment Plant Residuals Management. In: Water Quality and Treatment: A Handbook on Drinking Water. New York: McGraw Hill, 2011.

DI BERnARDO, L.; DANTAS, A. B. Métodos e Técnicas de Tratamento de Água. São Carlos: RIMA, 2005.

DRISCOLL, J.; RUPAKHETI, P.; BHATIA, S. K.; KHACHAN, M. M. Comparison of 1-D and 2-D tests in geotextile dewatering applications. International Journal of Geosynthetics and Ground Engineering, v. 2, n. 3, p. 1-9, 2016. https://doi.org/10.1007/s40891-016-0068-0

FOWLER, J.; BAGBY, R. M.; TRAINER, E. Dewatering Sewage Sludge with Geotextile tubes. Geotechnical Fabrics Report, v. 15, n. 7, p. 26-30, 1997.

GEOSYNTHETIC RESEARCH INSTITUTE. GRI Test Method GT15: standard test method for the pillow test for field assessment of fabrics/additives used for geotextile bags, containers, and tubes. Folsom, 2009.

GUIMARÃES, M. G. A.; URASHIMA, D. C.; VIDAL, D. M. Dewatering of sludge from a water treatment plant in geotextile closed systems. Geosynthetics International, v. 21, n. 5, p. 310-320, 2014. https://doi.org/10.1680/gein.14.00018

KNOCKE, W. R.; HAMON, J. R.; DUBLIN, B. E. Effects of coagulation on sludge thickening and dewatering. Journal American Water Works Association, v. 79, n. 6, p. 89-98, 1987. https://doi.org/10.1002/j.1551-8833.1987.tb02862.x

KOERNER, R. M.; KOERNER, G. R. Performance tests for the selection of fabrics and additives when used as geotextile bags, containers, and tubes. Geotechnical testing journal, v. 33, n. 3, p. 236-242, 2010. https://doi.org/10.1520/GTJ102686

LAWSON, C. R. Geotextile containment for hydraulic and environmental engineering. $\begin{array}{llllllll}\text { Geosynthetics International, } & \text { v. } 15 & \text { n. } & 6, & \text { p. 384-427, } 2008 .\end{array}$ https://doi.org/10.1680/gein.2008.15.6.384

LI, T.; ZHU, Z.; WANG, D.; YAO C; TANG H. The strength and fractal dimension characteristics of alum-kaolin flocs. International Journal of Mineral Processing, v. 82, p. 23-29, 2007. https://doi.org/10.1016/j.minpro.2006.09.012

MOO-YOUNG, H. K.; GAFFNEY, D. A.; MO, X. Testing procedures to assess the viability of dewatering with geotextiles tubes. Geotextiles and Geomembranes, v. 20, n. 5, p. 289303, 2002. https://doi.org/10.1016/S0266-1144(02)00028-6

MUTHUKUMARAN, A. E.; ILAMPARUTHI, K. Laboratory studies on geotextile filters as used in geotextile tube dewatering. Geotextiles and Geomembranes, v. 24, n. 4, p. 210-219, 2006. https://doi.org/10.1016/j.geotexmem.2006.03.002

OLIVEIRA, G. L. A.; VIDAL, D. M. Influence of sand addition in the early stage retention of fine sludge dewatering by geotextile. Revista Ambiente \& Água, v. 15, n. 3, 2020. https://doi:10.4136/ambi-agua.2527 
RATNAYESURAJ, C. R.; BHATIA, Shobha K. Testing and analytical modeling of twodimensional geotextile tube dewatering process. Geosynthetics International, v. 25, n. 2, p. 132-149, 2018.

SATYAMURTHY, R.; BHATIA, S. K. Effect of polymer conditioning on dewatering characteristics of fine sediment slurry using geotextiles. Geosynthetics International, v. 16, n. 2, p. 83-96, 2009. https://doi.org/10.1680/gein.2009.16.2.83

TOMINAGA, E. Análise dos procedimentos para avaliação de desempenho de sistemas fechados com geotêxtil para desaguamento. 2010. 126 p. Thesis (MSc in Aeronautical Infrastructure Engineering) - Aeronautics Institute of Technology, São José dos Campos, 2010.

TURCHIULI, C.; FARGUES, C. Influence of structural properties of alum and ferric flocs on sludge dewaterability. Chemical Engineering Journal, v. 103, n. 123-131, 2004. https://doi.org/10.1016/j.cej.2004.05.013 